\title{
SPA KAKI DENGAN BANTUAN KAYU REFLEKSI TERHADAP SATURASI OKSIGEN PADA DIABETESI
}

\author{
I Made Sukarja ${ }^{1}$, I Wayan Sukawana ${ }^{2}$ \\ 1,2 Jurusan Keperawatan Politeknik Kesehatan Denpasar \\ Denpasar, Bali, Indonesia
}

Email: md_sukarja@yahoo.co.id, wsukawanajkp@gmail.com

\begin{abstract}
Foot Spa with the Help of Wood Reflections on Oxygen Saturation in People with
Diabetes. The study was conducted with a quasi-experimental method, pre-test post test with control group design. The study used 2 (two) groups, group I was given treatment in the form of Foot SPA with the help of wood reflection every 2 days 15-30 minutes for 6 weeks, group II (control group) were given foot exercises every 2 days 15-30 minutes for 6 weeks. Saturation data were collected with digital oximetry at the beginning of the study and one day after the treatment period ended. Data were analyzed by paired and unpaired different tests. The results of the statistical independent test of the test that have been done show that the value of $p$ value is 0,000 ( $p$ value <0.05). This shows that there is a significant difference in oxygen saturation of the legs in the diabetics between the treatment groups that are given SPA reflective wooden foot SPA with a control group that is only given diabetic foot exercises. This can also be seen from the difference in the average oxygen saturation of the feet with diabetes in the treatment group by $4.52 \%$ and the control group by $0.28 \%$. The results of the analysis showed that the administration of reflex wooden aids on foot was more effective in increasing oxygen saturation of the feet compared to only foot exercises in the control group.
\end{abstract}

Key words: Foot Spa with the help of wood reflection, oxygen saturation

Abstrak: Spa Kaki dengan Bantuan Kayu Refleksi Terhadap Saturasi Oksigen pada Diabetisi. Tujuan penelitian ini adalah untuk mengetahui pengaruh SPA Kaki dengan bantuan kayu refleksi terhadap saturasi oksigen pada diabetisi di Denpasar Selatan. Penelitian dilaksanakan dengan metode quasieksperimen, pre test post test with control group design. Penelitian menggunakan 2 (dua) kelompok, kelompok I diberikan perlakuan berupa SPA Kaki dengan bantuan kayu refleksi setiap 2 hari 15 - 30 menit selama 6 minggu, kelompok II (kelompok kontrol) diberikan senam kaki tiap 2 hari 15 - 30 menit selama 6 minggu. Data Saturasi dikumpulkan dengan oksimetri digital pada awal penelitian dan satu hari setelah periode perlakuan berakhir. Data dianalisis dengan uji beda berpasangan dan tidak berpasangan. Hasil uji statistic independent sample $t$ test yang telah dilakukan menunjukkan bahwa nilai $p$ value 0,000 ( $p$ value $<0,05$ ) hal ini menunjukkan bahwa ada perbedaan bermakna saturasi oksigen kaki pada diabetisi antara kelompok perlakuakn yang diberikan SPA kaki berbantu kayu refleksi dengan kelompok kontrol yang hanya diberikan senam kaki diabetic. Hal ini juga dapat dilihat dari adanya perbedaan rerata saturasi oksigen kaki diabetisi pada kelompok perlakuan sebesar 4,52\% dan kelompok kontrol sebesar 0,28\%. Hasil analisis tersebut menunjukkan bahwa pemberian SPA kaki berbantu kayu refleksi lebih efektif meningkatkan saturasi oksigen kaki dibandingkan dengan hanya senam kaki pada kelompok kontrol.

Kata kunci: Spa Kaki dengan bantuan kayu refleksi, saturasi oksigen 


\section{PENDAHULUAN}

Organisasi Kesehatan Dunia atau World Health Organization (WHO) memperkirakan jumlah DM di dunia pada tahun 2000 sebesar 150 juta dan meningkat menjadi 300 juta pada tahun 2025 . Peningkatan prevalensi DM tertinggi terjadi di Asia Tenggara termasuk di Indonesia 1). Menurut 2), International Diabetes Federation (IDF) memprediksi peningkatan DM di Indonesia dari 9,1 juta pada tahun 2014 menjadi 14,1 juta pada tahun 2035. Jumlah 9,1 juta tersebut, telah menempatkan Indonesia pada urutan ke-5 negara dengan penyandang DM terbanyak di dunia. Hal tersebut memberikan kejutan karena Indonesia naik dua peringkat dalam kurun waktu satu tahun. Tahun 2013 Indonesia menempati urutan ke-7 penderita DM terbanyak di dunia dengan 7,6 juta penyandang DM.

Kasus diabetes melitus yang terbanyak ditemui di Indonesia adalah DM tipe $2^{3)}$. Hal ini berhubungan dengan perubahan gaya hidup yang sejalan dengan peningkatan sosial ekonomi masyarakat Indonesia. Dibandingkan dengan DM tipe lainnya, DM tipe 2 mengalami peningkatan $5-10$ kali lipat. Peningkatan yang pesat ini terjadi sebagai akibat perubahan perilaku tradisional -rural ${ }^{4)}$. Salah satu daerah di Bali yang sedang mengalami perkembangan tradisional-rural adalah Denpasar.

DM tipe 2 terjadi akibat dua faktor, yaitu tidak adekuatnya sekresi insulin (defisiensi insulin) dan kurang sensitifnya jaringan tubuh terhadap insulin (resistensi insulin) ${ }^{5)}$. Kurangnya sekresi insulin dan tidak sensitifnya jaringan tubuh terhadap insulin mengakibatkan glukosa menumpuk dalam aliran darah (hiperglikemia) ${ }^{4)}$. Pada tahap awal terjadi hiperglikemia akut postprandial yang kemudian menjadi hiperglikemia kronis ${ }^{5)}$. Disamping masalah hiperglikemia, resistensi insulin juga berdapak pada peningkatan kholesterol total serta kadar gliserida dalam darah ${ }^{6}$. Penelitian ${ }^{7)}$ membuktikan bahwa seluruh
(100\%) pasien DM yang ditelitinya memiliki nilai cholesterol total dan trigliserida yang tinggi.

Hiperglikemia kronis mengakibatkan kelompok sel non insulin dependent seperti sel endotel pembuluh darah kebanjiran glukosa (hiperglisolia). Hiperglisolia kronik mengakibatkan perubahan homeostasis biokimiawi intra sel sehingga sel endotel rusak. Glukosa diubah menjadi zat yang sangat didrofilik yaitu sorbitol dan fruktosa sehingga membran pembuluh darah menjadi bengkak dan tebal ${ }^{8)}$. Kelainan pembuluh darah tersebut diperparah dengan penurunan produksi Nitrous Oksida lokal sebagai akibat resistensi insulin. Berkurangnya NO mengakibatkan kemampuan pembuluh darah dalam mencegah penempelan asam lemak dan trigliserida pada dinding endotelium menurun sehingga pembuluh darah menjadi kaku ${ }^{9}$.

Kelainan dan kekakuan pembuluh darah dapat terjadi pada berbagai organ, termasuk pembuluh darah perifer tungkai bawah ${ }^{10)}$. Lokasi yang terkena terutama pada aorta abdominal dan arteri iliaka (30\% dari pasien yang simtomatik), arteri femoralis dan poplitea (80-90\%), termasuk arteri tibialis dan peroneal $(40-50 \%)^{11)}$. Manifestasi gangguan pembuluh darah pada tungkai bawah adalah penurunan suplai darah ke kaki. Penurunan suplai darah ke kaki mengakibatkan berkurangnya kadar oksigen pada bagian kaki. Hasil penelitian menemukan terjadi penuruan saturasi oksigen pada kaki penderita DM dengan angka $65 \%$, seharusnya adalah $90 \%{ }^{12)}$.

Masalah penurunan aliran darah ke kaki merupakan hal yang paling penting harus dicari dan harus diperhatikan dalam pengelolaan DM sehari-hari ${ }^{8}$. Penurunan aliran darah ke kaki berisiko terjadinyya kaki diabetik ${ }^{10)}$. Prevalensi kaki diabetik di Amerika Serikat sebesar 15-20\%, sedangkan di Indonesia sekitar $15 \%{ }^{13)}$.

Kaki diabetik merupakan masalah serius karena angka amputasi mencapai 
$30 \%$, angka mortalitas $32 \%$, dan (80\%) sebagai penyebab utama diabetesi harus dirawat di rumah sakit ${ }^{13}$ ). Beberapa pusat penelitian di Indonesia mendapatkan angka kematian ulkus/ gangrene diabetes berkisar antara $17-32 \%$ sedangkan laju amputasi antara 15-30\%. Nasib pasien pasca amputasi juga tidak menggembirakan ${ }^{11)}$. Dalam satu tahun pasca amputasi $14,8 \%$ meninggal, meningkat menjadi $37 \%$ dalam pengamatan selama tiga tahun. Rerata umur pasien hanya 23.8 bulan pasca amputasi Kaki diabetik memberi dampak pada beban ekonomi yang sangat tinggi. Di Kanada rata-rata biaya perawatan untuk pasien DM dengan kaki diabetik mencapai \$ 52.360 dalam waktu 3 tahun ${ }^{14)}$. Penanganan kaki diabetik di Indonesia memerlukan biaya 1,3 sampai 1,6 juta rupiah perbulan ${ }^{13)}$.

Mempertimbangkan seriusnya masalah kaki diabetik serta beban ekonomi yang ditimbulkan, maka masalah kaki diabetik harus dicegah sedini mungkin. Upaya yang sedang digalakkan dewasa ini adalah dengan senam kaki. Hasil-hasil penelitian membuktikan bahwa senam kaki terbukti efektif meningkatkan sirkulasi kaki. Penelitian lain membuktikan bahwa sirkulasi kaki dapat dinaikan dengan pemberian latihan rentang gerak sendi (ROM). Latihan rentang gerak sendi juga dapat menurunkan keluhan neuropati ${ }^{15}$. Penelitian upaya perawatan komplementer yang dilakukan adalah dengan refleksi. Penelitian ${ }^{16)}$ membuktikan bahwa terapi pijat refleksi kaki berpengaruh signifikan dalam meningkatkan sirkulasi pada pasien diabetes melitus tipe 2 di RS PKU Muhammadiyah Gombong.

Pencegahan kaki dibetik dapat dilakukan dengan memperbaiki vaskularisasi kaki. Vaskularisasi kaki dapat ditingkatkan dengan melakukan senam kaki secara teratur. Kelembaban kulit kaki juga harus dijaga agar tidak kering dan tidak mudah retak. Stimulasi kutaneus dapat dilakukan untuk meningkatkan integrasi sensori dan aktivitas system saraf otonom ${ }^{17)}$. Penggunaan Virgin Coconut Oil (VCO) atau minyak kelapa murni pada stimulasi kutan mengakibatkan asam lemak berikatan dengan keringat kemudian melapisi permukaan kulit sehingga dapat menahan air di stratum corneum ${ }^{18)}$.

Beberapa hasil penelitian tersebut merupakan tindakan yang terpisah sehingga para diabetisi masih kesulitan melakukan sendiri. Para diabetisi sangat membutuhkan tindakan yang mudah dan menarik untuk dilakukan. Hal ini untuk mendorong agar para diabetisi dapat melakukan secara rutin.

Berdasarkan alasan tersebut diatas, peneliti tertarik untuk melakukan upaya perbaikan sirkulasi kaki melalui pendekatan teknik SPA kaki diabetik. Teknik SPA kaki diabetic merupakan penggabungan senam kaki dan perawatan kaki serta refleksi pada kaki. Senam kaki merupakan upaya memperbaiki sirkulasi pada kaki dan perawatan kaki ditujukan untuk menjaga elastisitas kulit dan kelembaban kulit kaki. Isitilah SPA memberikan daya tarik bagi para diabetisi untuk melakukannya karena mengadung isitilah kecantikan. SPA diabetic merupakan istilah yang dirancang untuk program latihan dan perawatan kulit.

\section{METODE}

Jenis penelitian ini adalah quasieksperimen dengan menggunakan rancangan pre test post test with control group design. Penelitian ini menggunakan 2 (dua) kelompok, kelompok I adalah kelompok perlakukan yang diberikan perlakukan berupa latihan rentang gerak kaki dengan bantuan kayu refleksi. Kelompok II disebut kelompok kontrol yang mendapatkan perlakuan standar berupa senam kaki. Saturasi pada kedua kelompok diukur sebelum dan setelah diberi tindakan selama 6 minggu. Penelitian ini dilakukan di wilayah kerja Puskesmas Denpasar Selatan, bulan Agustus - Oktober 2019. 
Populasi sampel dibatasi (kriteria inklusi) pada diabetisi yang minimal telah satu tahun terdiagnosa diabetes melitus. Jumlah sampel yang diteliti sebanyak 20 diabetisi untuk tiap kelompok diambil dengan teknik acak sederhana.

Data saturasi oksigen di kumpulkan dengan pemeriksaan saturasi oksigen menggunakan alat oksometry Digital. Dan bahan untuk refleksi mengggunakan kayu bergerigi dengan ukuran $20 \times 10 \mathrm{~cm}$, dengan gerigi yang tumpul. Analisis perbedaan pengaruh SPA Kaki dengan bantuan kayu refleksi dibandingkan dengan pengaruh senam kaki terhadap saturasi oksigen dilakukan dengan uji beda dua kelompok populasi tidak berpasangan dengan tingkat kepercayaan $95 \%$ atau dengan alpa 0,05 . Uji beda tidak berpasangan parametrik dapat dilakukan dengan syarat data berdistribusi normal. Pengambilan kesimpulan berdasarkan nilai signifikan. Jika nilai signifikan lebih kecil alpa, maka HO ditolak.

\section{HASIL DAN PEMBAHASAN}

Data karakteristik responden berdasarkan jenis kelamin yang didapatkan dari 25 responden pada kelompok perlakuan dan 25 responden pada kelompok kontrol disajikan dalam tabel 1 berikut :

Tabel 1. Distribusi Karakteristik

Responden Berdasarkan Jenis

Kelamin di Wilayah Kerja

Denpasar Selatan Tahun 2019

\begin{tabular}{lcccc}
\hline \multirow{2}{*}{ Jenis } & \multicolumn{2}{c}{ Perlakuan } & \multicolumn{2}{c}{ Kontrol } \\
Kelam & $\begin{array}{c}\text { Freku } \\
\text { in } \\
\text { ensi } \\
(\mathrm{n})\end{array}$ & $\begin{array}{c}\text { Prese } \\
\text { ntase } \\
(\%)\end{array}$ & $\begin{array}{c}\text { Freku } \\
\text { ensi } \\
(\mathrm{n})\end{array}$ & $\begin{array}{c}\text { Prese } \\
\text { ntase } \\
(\%)\end{array}$ \\
\hline $\begin{array}{l}\text { Laki- } \\
\text { laki }\end{array}$ & 13 & 52 & 14 & 56 \\
$\begin{array}{l}\text { Perem } \\
\text { puan }\end{array}$ & 12 & 48 & 11 & 44 \\
\hline $\begin{array}{l}\text { Jumla } \\
\text { h }\end{array}$ & 25 & 100 & 25 & 100 \\
\hline
\end{tabular}

Tabel di atas menunjukkan sebagian besar responden berjenis kelamin laki yakni sebanyak 13 orang (52\%) pada kelompok perlakuan dan 14 orang $(56 \%)$ pada kelompok kontrol.

Tabel 2. Karakteristik Responden Berdasarkan Usia di Wilayah Kerja Denpasar Selatan Tahun 2019

\begin{tabular}{ccccc}
\hline \multirow{2}{*}{ Usia } & \multicolumn{2}{c}{ Perlakuan } & \multicolumn{2}{c}{ Kontrol } \\
\cline { 2 - 5 } & $\mathrm{f}(\mathrm{n})$ & $(\%)$ & $\mathrm{F}(\mathrm{n})$ & $(\%)$ \\
\hline $50-59$ & 8 & 32 & 7 & 28 \\
$60-69$ & 13 & 52 & 13 & 52 \\
$70-79$ & 4 & 16 & 5 & 20 \\
\hline Jumlah & 25 & 100 & 25 & 100 \\
\hline
\end{tabular}

Berdasarkan tabel diatas, kelompok usia responden terbanyak adalah pada usia 6069 tahun baik pada kelompok perlakuan maupun pada kelompok kontrol yakni berjumlah sama, yaitu sebanyak 13 orang $(52 \%)$.

Tabel 3. Karakteristik Responden Berdasarkan Usia di Wilayah Kerja Denpasar Selatan 2019

\begin{tabular}{ccccc}
\hline Lama & \multicolumn{2}{c}{ Perlakuan } & \multicolumn{2}{c}{ Kontrol } \\
\cline { 2 - 5 } Menderita & $\mathrm{f}(\mathrm{n})$ & $(\%)$ & $\mathrm{f}(\mathrm{n})$ & $(\%)$ \\
DM & & & & \\
\hline $1-5$ & 11 & 44 & 21 & 84 \\
$6-10$ & 13 & 52 & 4 & 16 \\
$11-15$ & 1 & 4 & 0 & 0 \\
\hline Jumlah & 25 & 100 & 25 & 100 \\
\hline
\end{tabular}

Berdasarkan tabel diatas, karakteristik responden berdasarkan lamanya menderita terlama pada kelompok perlakuan yaitu sebanyak 13 orang $(52 \%)$ dengan lama menderita DM selama 6-10 tahun, sedangkan pada kelompok perlakuan karakteristik penderita DM terbanyak sebesar 21 (84\%) orang dengan lama menderita DM selama 1-5 Tahun 
Tabel 4. Saturasi Oksigen Kaki Kelompok Perlakuan dan Kontrol Sebelum Diberikan SPA Kaki Berbantu Kayu Refleksi Pada Kelompok Perlakuan dan Senam Kaki Pada Kelompok Kontrol

\begin{tabular}{ccccc}
\hline \multirow{2}{*}{ Saturasi } & \multicolumn{2}{c}{ Kelompok } & \multicolumn{2}{c}{ Kelompok } \\
Oksigen & \multicolumn{2}{c}{ Perlakuan } & \multicolumn{2}{c}{ Kontrol } \\
& $\mathrm{f}$ & $(\%)$ & $\mathrm{f}$ & $(\%)$ \\
\hline 92 & 4 & 16,0 & 5 & 20,0 \\
93 & 3 & 12,0 & 3 & 12,0 \\
94 & 8 & 32,0 & 9 & 36,0 \\
95 & 10 & 40,0 & 8 & 32,0 \\
\hline Jumlah & 25 & 100,0 & 25 & 100,0 \\
\hline
\end{tabular}

Berdasarkan interpretasi table 4 diatas, dari 25 responden pada kelompok perlakuan sebelum diberikan SPA Kaki dengan bantuan kayu refleksi didapatkan bahwa nilai saturasi oksigen perifer kaki terbanyak adalah $95 \%$ dengan jumlah 10 responden $(40,0 \%)$ dan pada kelompok kontrol saturasi oksigen perifer kaki terbanyak adalah 94\% dengan jumlah 9 responden $(36,0 \%)$. Hasil analisis pada penelitian ini menunjukkan saturasi oksigen kaki pada kelompok perlakuan sebelum diberikan SPA kaki diabetic berbantu kayu refleksi memiliki rata-rata 93,96\% dengan standar deviasi 1,098. Dari keseluruhan pengukuran saturasi oksigen yang diperoleh, saturasi oksigen kaki terendah adalah $92 \%$ dan tertinggi $95 \%$. Nilai saturasi oksigen ini dikatakan terganggu karena nilai saturasi oksigen kaki $\leq 95 \%$. Ini menunjukkan terjadinya gangguan sirkulasi darah menuju ke perifer kaki dan menurunnya hantaran oksigen di bagian kaki. Hal serupa juga terjadi pada responden kelompok kontrol yang memiliki rata rata saturasi oksigen kaki sebesar 93,80\% dengan standar deviasi 1,118 dan saturasi oksigen kaki terendah pada kelompok kontrol adalah 92\%. Ini menunjukkan rata-rata saturasi oksigen kaki pada kelompok kontrol juga mengalami penurunan saturasi oksigen kaki.
Penurunan saturasi oksigen perifer disebabkan oleh adanya proses makroangiopati pada pembuluh darah sehingga sirkulasi jaringan menurun. Penimbunan sorbitol dalam intima vaskuler dan hiperlipoproteinemia yang disebabkan oleh hiperglikemi mengakibatkan penyumbatan vaskuler yang terjadi karena penebalan tunika intima (hiperplasia membran basalis arteri) pada pembuluh darah besar dan pembuluh kapiler bahkan dapat terjadi kebocoran albumin keluar kapiler sehingga mengganggu distribusi darah ke jaringan sehingga sirkulasi darah terganggu. Jika hal ini terjadi pada arteri perifer dapat mengakibatkan insufiensi pembuluh darah perifer yang disertai klaudikasio intermiten 19). Gangguan sirkulasi darah pada ekstermitas bawah dapat menurunkan hantaran oksigen pada jaringan yang menyebabkan penurunan saturasi oksigen perifer ${ }^{20)}$. Teori ini didukung oleh penelitian yang dilakukan oleh Parameswaran, Brand and Dolan (2005) dengan judul Pulse Oximetry as a Potential Screening Tool For Lower Extermity Arterial Disease in Asymptomatic Patients With Diabetes Mellitus yang menyatakan bahwa dari 35 kaki yang mengalami lower ekstermity artery disease (LEAD) sebanyak 27 kaki mengalami gangguan saturasi oksigen.

Pasien diabetes mellitus memiliki resiko mengalami penurunan sirkulasi darah ke bagian perifer dan ditandai dengan penurunan saturasi oksigen perifer. Jika penuruan sirkulasi ke bagian kaki berlanjut, tanpa adanya solusi yang efektif dapat berdampak pada metabolisne sel. Penuruan metabolisme dalam jangka waktu yang lama menggambarkan bahwa terjadi perubahn metabolisme anaerob menghasilkan asam laktat yang dikeluhkan dengan rasa nyeri, kebas dan pegal-pegal dan berlanjut menjadi kaki diabetik ${ }^{10}$. 
Tabel 5. Distribusi Saturasi Oksigen Pada Diabetisi Setelah Diberikan SPA Kaki Berbantu Kayu Refleksi Pada Kelompok Perlakuan dan Senam Kaki Pada Kelompok Kontrol

\begin{tabular}{ccccc}
\hline $\begin{array}{c}\text { Saturasi } \\
\text { Oksigen } \\
\text { Kaki }\end{array}$ & \multicolumn{2}{c}{$\begin{array}{c}\text { Kelompok } \\
\text { Perlakuan }\end{array}$} & \multicolumn{2}{c}{$\begin{array}{c}\text { Kelompok } \\
\text { Kontrol }\end{array}$} \\
\cline { 2 - 5 }$(\%)$ & $\mathrm{F}$ & $\%$ & $\mathrm{f}$ & $\%$ \\
\hline 92 & 0 & 0,0 & 1 & 4,0 \\
93 & 0 & 0,0 & 4 & 16,0 \\
94 & 0 & 0,0 & 12 & 48,0 \\
95 & 0 & 0,0 & 8 & 32,0 \\
96 & 0 & 0,0 & 0 & 0,0 \\
97 & 1 & 4,0 & 0 & 0,0 \\
98 & 11 & 44,0 & 0 & 0,0 \\
99 & 13 & 52,0 & 0 & 0,0 \\
\hline Jumlah & 25 & 100,0 & 25 & 100,0 \\
\hline
\end{tabular}

Berdasarkan interpretasi table 5 diatas, saturasi oksigen kaki terbanyak pada kelompok perlakuan adalah 99\% dengan jumlah responden sebanyak 13 responden $(52,0 \%)$. Sedangkan pada kelompok kontrol saturasi oksigen kaki terbanyak adalah 95\% dengan jumlah responden sebanyak 12 responden $(48,0 \%)$.

Tabel 6. Perbedaan Saturasi Oksigen Pada Kelompok Perlakuan Sebelum dan Setelah Diberikan SPA Kaki Dengan Bantuan Kayu Refleksi.

\begin{tabular}{ccccc}
\hline $\begin{array}{c}\text { Variabe } \\
1\end{array}$ & $\begin{array}{c}\text { Mea } \\
\text { Saturasi } \\
\text { Oksigen }\end{array}$ & SD & $\begin{array}{c}\text { Mean } \\
\text { Selisi } \\
\mathrm{h}\end{array}$ & $\begin{array}{c}\mathrm{P} \\
\text { Valu } \\
\mathrm{e}\end{array}$ \\
\hline $\begin{array}{c}\text { Sebelu } \\
\mathrm{m}\end{array}$ & $\begin{array}{c}93,9 \\
6\end{array}$ & $\begin{array}{c}1,09 \\
8\end{array}$ & & \\
Setelah & $\begin{array}{c}98,4 \\
0,65\end{array}$ & 4,52 & 0,000 \\
& 8 & 3 & & \\
\hline
\end{tabular}

Tabel 6 diatas menunjukkan bahwa selisih rata-rata pengukuran saturasi oksigen kaki pada diabetisi sebelum dan sesudah diberikan SPA kaki dengan bantuan kayu refleksi pada kelompok perlakuan adalah 4,52. Hasil uji statistik pada kelompok perlakuan didapatkan nilai $\mathrm{p}$ value sebesar 0,000 ( $\mathrm{p}$ value $<0,05$ ) sehingga dapat disimpulkan bahwa $\mathrm{H}_{0}$ ditolak dan ada perbedaan yang signifikan antara saturasi oksigen kaki diabetisi sebelum dan setelah diberikan SPA Kaki dengan bantuan kayu refleksi. Hal ini menunjukkan bahwa terjadi peningkatan saturasi oksigen kaki yang bermakna dari rata-rata saturasi oksigen 93,96 menjadi 98,48 setelah diberikan SPA Kaki dengan bantuan kayu refleksi. Hasil analisis terhadap saturasi oksigen kaki diabetisi pada kelompok perlakuan setelah melakukan SPA kaki berbantu kayu refleksi memiliki rata-rata sebesar $98,48 \%$ dengan standar deviasi 0,653. Dari keseluruhan pengukuran saturasi oksigen yang diperoleh, saturasi oksigen kaki terendah adalah $97 \%$ dan tertinggi $99 \%$. Ini menunjukkan terjadi peningkatan saturasi oksigen kaki sebelum dan setelah diberikan SPA kaki diabetic berbantu kayu refleksi. Sedangkan pada responden kelompok kontrol yang memiliki rata rata saturasi oksigen kaki sebesar 94,08\% dengan standar deviasi 0,812 dan saturasi oksigen kaki terendah pada kelompok kontrol setelah senam kaki adalah 92\% dan tertinggi sebesar 95\%. Ini menunjukkan rata-rata saturasi oksigen kaki pada kelompok kontrol juga mengalami peningkatan walaupun tidak lebih besar dari peningkatan yang terjadi pada kelompok perlakuan.

Terjadinya peningkatan rata-rata saturasi oksigen pada kelompok perlakuan dan kontrol karena peningkatan sirkulasi darah kebagian perifer kaki. Namun kenaikan yang terjadi pada kelompok kontrol berbeda dengan kenaikan yang terjadi pada kelompok perlakuan yang disebabkan karena adanya perbedaan perlakuan yang diberikan.

Peningkatan saturasi oksigen juga terjadi pada peningkatan saturasi oksigen perifer kaki setelah dilakukan perlakuan 
berupa connective tissue reflex massage selama 30 menit terjadi peningkatan sirkulasi darah yang diukur dengan hasil saturasi oksigen perifer pada kaki. Ratarata saturasi oksigen perifer kaki kanan 94,56\% menjadi 97,92\% dan dari rata-rata saturasi oksigen perifer kaki kiri 94,53\% menjadi $98,09 \%{ }^{22)}$.

Tabel 7. Perbedaan Saturasi Oksigen Pada Kelompok Kontrol Sebelum dan Setelah Diberikan Senam Kaki

\begin{tabular}{ccccc}
\hline Saturasi & $\begin{array}{c}\text { Mea } \\
\text { Oksigen }\end{array}$ & SD & $\begin{array}{c}\text { Selisi } \\
\text { Mean }\end{array}$ & $\begin{array}{c}\mathrm{P} \\
\text { Valu } \\
\mathrm{e}\end{array}$ \\
\hline $\begin{array}{ccccc}\text { Sebelu } \\
\mathrm{m}\end{array}$ & $\begin{array}{c}93,8 \\
0\end{array}$ & $\begin{array}{c}1,11 \\
8\end{array}$ & & \\
Setelah & $\begin{array}{c}94,0 \\
0\end{array}$ & $\begin{array}{c}0,81 \\
2\end{array}$ & & \\
& 8 & 28,032 & \\
\hline
\end{tabular}

Tabel 7 diatas menunjukkan bahwa selisih rata-rata pengukuran saturasi oksigen kaki pada diabetisi pada kelompok kontrol setelah diberikan senam kaki adalah 0,28. Hasil uji statistik pada kelompok kontrol didapatkan nilai $\mathrm{p}$ value sebesar $0,032(\mathrm{p}$ value $<0,05$ ) sehingga dapat disimpulkan bahwa $\mathrm{H}_{0}$ ditolak dan ada perbedaan yang signifikan antara saturasi oksigen kaki diabetisi sebelum dan setelah diberikan senam kaki. Hal ini menunjukkan bahwa terjadi peningkatan saturasi oksigen kaki yang bermakna dari rata-rata saturasi oksigen 93,80 menjadi 94,08 dengan hanya memberikan senam kaki bagi kelompok kontrol, namun peningkatan rata-rata tidak sesignifikan peningkatan rata-rata pada kelompok perlakuan. Hasil penelitian menunjukkan saat pengukuran saturasi oksigen pada kelompok kontrol diperoleh rata-rata hasil pengukuran $93,80 \%$. Setelah 6 minggu, pengukuran kembali dilakukan dan diperoleh rata-rata $94,08 \%$. Selisih saturasi oksigen kaki kelompok kontrol mengalami peningkatan sebesar $0,28 \%$.Hasil uji statistic menggunakan paired $t$ test saturasi oksigen kelompok kontrol pada pengukuran awal dan pengukuran hasil memperoleh hasil $\mathrm{p}$ value $0,034$ ( $p$ value $<0,05)$. Hal ini menunjukkan bahwa terdapat perbedan yang signifikan antara saturasi oksigen kaki kelompok kontrol pada pengukuran awal dan akhir, hal ini sesuai dengan manfaat senam kaki diabetik yaitu dapat memperbaiki sirkulasi darah dan mampu memperkuat otot - otot kecil. Selain itu suplai darah yang menuju ke pembuluh darah perifer tidak mengalami hambatan sehingga oksigen dalam darah juga dapat didistribusikan dengan baik ${ }^{3)}$.

Peningkatan sirkulasi ini terjadi karena senam kaki dapat memperbaiki sirkulasi darah dan memperkuat otot-otot kecil, seperti meningkatkan kekuatan otot betis dan otot paha ${ }^{3}$. Salah satu gerakan dalam senam kaki adalah dorsofleksi dan plantar fleksi (otot-otot tungkai). Ketika terjadi pergerakan tungkai, akan mengakibatkan menegangnya otot-otot tungkai dan menekan vena disekitar otot tersebut. Hal ini akan mendorong darah kearah jantung dan tekanan vena akan menurun, mekanisme ini dikenal dengan pompa vena. Mekanisme ini akan membantu memperlancar peredaran darah bagian kaki dan memperbaiki sirkulasi darah ${ }^{23)}$. Peredaran darah yang lancar menghambat proses penebalan dari membrane kapiler, peningkatan ukuran dan jumlah sel endotel kapiler, sehingga diameter lumen pembuluh darah tetap adekuat khususnya pembuluh darah kapiler.

Berdasarkan hasil uji parametric pada kelompok perlakuan dan kelompok kontrol diperoleh data tingkat rata-rata saturasi oksigen kaki diabetisi yang disajikan dalam bentuk gambar dibawah ini: 
Gambar 1 Perbandingan rata-rata saturasi oksigen kaki pada kelompok perlakuan dan kelompok kontrol

Hasil uji statistic independent sample t test yang telah dilakukan menunjukkan bahwa nilai $p$ value 0,000 ( $p$ value $<0,05$ ) hal ini menunjukkan bahwa ada perbedaan bermakna saturasi oksigen kaki pada diabetisi antara kelompok perlakuakn yang diberikan SPA kaki berbantu kayu refleksi dengan kelompok kontrol yanghanya diberikan senam kaki diabetic. Hal ini juga dapat dilihat dari adanya perbedaan rerata saturasi oksigen kaki diabetisi pada kelompok perlakuan sebesar $4,52 \%$ dan kelompok kontrol sebesar 0,28\%.

Hasil analisis tersebut menunjukkan bahwa pemberian SPA kaki berbantu kayu refleksi lebih efektif meningkatkan saturasi oksigen kaki dibandingkan dengan hanya senam kaki pada kelompok kontrol. Hal yang membedakan pada kelompok perlakuan dan kelompok kontrol adalah pada kelompok perlakuan memperoleh perlakuan yang SPA kaki yang didalamnya terdapat senam kaki, pembersihan dan perendaman kaki dengan air hangat dan garam serta pijat kaki yang dibantu kayu refleksi yang dilakukan setiap 2 hari sekali dengan durasi 30 menit selama 6 minggu sedangkan kelompok kontrol hanya melakukan senam kaki diabetic setiap 2 hari sekali dengan durasi 30 menit selama 6 minggu.

Adanya pengaruh dalam penelitian ini terjadi karena SPA kaki berbantu kayu refleksi menstimulasi diabetisi untuk melakukan aktifitas fisik secara teratur. Senam kaki tidak mampu meningkatkan saturasi oksigen kaki secara cepat dibandingkan peningkatan saturasi oksigen kaki pada kelompok perlakuan yang diberikan SPA kaki diabetic dan berbantu kayu refleksi. Hal ini dapat dilihat pada selisih rata-rata pre-test dan post test pada kelompok perlakuan yang diberikan perlakuan SPA kaki diabetic berbantu kayu refleksi sebanyak dua kali sehari dengan durasi 30 menit dalam kurun waktu 6 minggu.

Hal ini sejalan dengan penelitian yang dilakukan Mar et al. (2011), bahwa terjadi peningkatan saturasi oksigen perifer kaki setelah dilakukan perlakuan berupa connective tissue reflex massage selama 30 menit terjadi peningkatan sirkulasi darah yang diukur dengan hasil saturasi oksigen perifer pada kaki. Rata-rata saturasi oksigen perifer kaki kanan 94,56\% menjadi 97,92\% dan dari rata-rata saturasi oksigen perifer kaki kiri 94,53\% menjadi 98,09\%.

Spa kaki diabetic yang terdiri dari senam kaki, skin cleansing, dan foot massage memiliki tujuan yang sama yaitu memperbaiki sirkulasi darah perifer dan membuat pasien merasa nyaman dan rileks pada pasien diabetes mellitus ${ }^{24)}$. Senam kaki diabetic dapat melancarkan peredaran darah serta meningkatkan kesehatan dan kebugaran tubuh 24). Senam kaki dapat memperbaiki sirkulasi darah dan memperkuat otot-otot kecil kaki dan mencegah terjadinya kelainan bentuk kaki. Pasien diabetes mellitus yang melakukan senam kaki akan terjadi pergerakan tungkai yang akan mengakibatkan mengakibatkan menegangnya otot-otot tungkai dan menekan vena disekitar otot tersebut. Hal ini akan mendorong darah kearah jantung dan tekanan vena akan menurun, mekanisme ini dikenal dengan pompa vena. Mekanisme ini akan membantu memperlancar peredaran darah bagian kaki dan memperbaiki sirkulasi darah ${ }^{23)}$.

Skin cleansing yang dilakukan setelah tindakan senam kaki diabetic juga dapat memperbaiki sirkulasi darah. Skin cleansing yang terdiri dari perendaman 
kaki menggunakan air hangat dan garam dapat memperlancar aliran darah pada vena sehingga terjadi reaksi vasodilatasi pada pembuluh darah ${ }^{26)}$.

Selain senam kaki dan skin cleansing, tindakan foot massage juga dapat memperlancar sirkulasi darah, memberi efek relaksasi dan melemaskan otot-otot yang tegang ${ }^{28}$. Tindakan foot massage dapat mempengaruhi hormone tubuh, yaitu dapat meningkatkan sekresi endofrin. Endofrin memiliki efek narkotika alami yaitu mengurangi rasa sakit dan meningkatkan kegembiraan. Endofrin menyebabkan vasodilatasi pembuluh darah sehingga dapat meningkatkan sirkulasi darah perifer. Terapi pijat refleksi kaki dapat mempengaruhi hormone tubuh yaitu dpat meningkatkan sekresi endorphin. Endorphin memiliki efek narkotika alami yaitu mengurangi rasa sakit, meningkatkan kegembiraan dan menyebabkan vasodilatasi pembuluh darah ${ }^{23)}$.

Ketiga tindakan dalam spa kaki tersebut memiliki tujuan yang sama yaitu memperbaiki sirkulasi darah. Hal ini berarti bahwa tindakan spa kaki diabetic yang diberikan pada 25 responden yang diberikan perlakuan dapat meningkatkan sirkulasi darah perifer sehingga dapat meningkatkan saturasi oksigen perifer lebih cepat dibandingkan pada kelompok kontro yang hanya diberikan senam kaki diabetic. Spa kaki merupakan perawatan secara menyeluruh dimana perawatan kaki adalah salah satu factor yang mempengaruhi sirkulasi darah perifer.

\section{SIMPULAN}

Berdasarakan hasil penelitian dan pembahasan dapat disimpulkan: rata-rata saturasi oksigen kaki pada kelompok perlakuan sebelum diberikan SPA kaki berbantu kayu refleksi menunjukkan nilai saturasi oksigen yang tergolong rendah yakni 93,96\% dan setelah diberikan SPA kaki berbantu kayu refleksi meningkat menjadi $98,48 \%$.
Rata-rata saturasi oksigen kaki pada kelompok kontrol sebelum diberikan senam kaki diabetic juga menunjukkan nilai saturasi oksigen yang tergolong rendah yakni $93,80 \%$ dan setelah diberikan senam kaki diabetic mengalami sedikit peningkatan menjadi $94,08 \%$.

Saturasi oksigen kaki pada kelompok perlakuan mengalami peningkatan sebesar $4,52 \%$. Hasil analisis paired $t$ test menunjukkan terdapat perbedaan yang bermakna nilai rata-rata saturasi oksigen kaki pada kelompok perlakuan antara sebelum dan sesudah diberikan SPA kaki berbantu kayu refleksi dengan $p$ value 0,000. Saturasi oksigen kaki pada kelompok kontrol mengalami peningkatan sebesar $0,28 \%$. Hasil analisis paired t test menunjukkan terdapat perbedaan nilai ratarata saturasi oksigen kaki pada kelompok perlakuan antara sebelum dan sesudah diberikan senam kaki diabetik dengan $p$ value 0,034 .

Hasil analisis mengenai pengaruh SPA kaki berbantu kayu refleksi terhadap saturasi oksigen diabetisi pada kelompok perlakuan dan kontrol yang telah dilakukan di Puskesmas IV Denpasar Selatan dan Puskesmas I Denpasar Selatan diperoleh hasil $p$ value (Sig. 2 Tailed) sebesar 0,000 ( $p$ value $<0,05$ ) yang berarti ada pengaruh SPA kaki berbantu kayu refleksi terhadap saturasi oksigen diabetisi pada kelompok perlakuan dan control.

\section{UCAPAN TERIMA KASIH}

Ucapan terima kasih disampaikan kepada Bapak Diektur Poltekkes Kemenkes Denpasar yang telah memberi kesempatan dan dukungan dana sehingga penilitan dapat berjalan dengan lancar. Ucapan terima aksih juga disampaikan kepada Kepala Dinas Kesehatan Kota Denpasar dan Kepala Puskesmas Denpasar Selatan yang telah memberikan ijin sebagai lokasi penelitian sehingga pengambilan sample sesuai dengan target. 


\section{ETIKA PENELITIAN}

Etika penelitian diperoleh dari Komisi Etik Penelitian Politeknik Kesehatan Kemenkes Denpasar nomer : LB.02.03./EA/KEPK/0467/2019.

\section{SUMBER DANA}

Penelitian ini mendapat dana dari DIPA Poltekkes Kemenkes Denpasar tahun 2019 dengan Surat Perjanjian Pelaksanaan Penelitian Nomor DP.02.01/PPK/5358/2019.

\section{DAFTAR PUSTAKA}

1. Suyono S. Diabetes Melitus di Indonesia. In: Setiati S, Alwi I, Sudoyo AW, Simadibrata K M, Setyohadi B, Syam AF, editors. Buku Ajar Ilmu Penyakit Dalam. VI. Jakarta: InternaPublishing; 2014. p. 2315-22.

2. Soelistijo SA, Novida H, Rudijanto A, Soewondo P, Suastika K, Manaf A, et al. Konsensus Pengendalian dan Pencegahan Diabetes Melitus Tipe 2 di Indonesia 2015 [Internet]. Perkeni. PB Perkeni; 2015. 78 p. Available from: http://pbperkeni.or.id/doc/konsensus.p df

3. Soegondo S. Farmakoterafi pada Pengendalian Glikemia Diabetes Melitus Tipe 2. In: Setiati S, Alwi I, Sudoyo AW, Simadibrata K M, Setyohadi B, Syam AF, editors. Buku Ajar Ilmu Penyakit Dalam. VI. Jakarta: InternaPublishing; 2014. p. 2328-35.

4. Purnamasari D. Diagnosis dan Klasifikasi Diabetes Melitus. In: Setiati S, Alwi I, Sudoyo AW, Simadibrata K M, Setyohadi B, Syam AF, editors. Buku Ajar Ilmu Penyakit Dalam. VI. Jakarta: InternaPublishing; 2014. p. 2323-7.

5. Manaf A. Insulin: Mekanisme Sekresi dan Aspek Metabolisme. In: Setiati S, Alwi I, Sudoyo AW, Simadibrata K M, Setyohadi B, Syam AF, editors. Buku Ajar Ilmu Penyakit Dalam. VI.
Jakarta; 2014. p. 2350-4.

6. Sihab A. Komplikasi Kronik DM Penyakit Jantung Koroner. In: Setiati S, Alwi I, Sudoyo AW, Simadibrata K M, Setyohadi B, Syam AF, editors. Buku Ajar Ilmu Penyakit Dalam. VI. Jakarta: InternaPublishing; 2014. p. 2414-9.

7. Hasona N, Elasbali A. Evaluation of Electrolytes Imbalance and Dyslipidemia in Diabetic Patients. Med Sci [Internet]. 2016;4(2):7. Available from: http://www.mdpi.com/2076$3271 / 4 / 2 / 7$

8. Waspadji S. Komplikasi Kronik Diabetes: Mekanisme Terjadinya, Diagnosis, dan Strategi Pengelolaan. In: Setiati S, Alwi I, Sudoyo AW, Simadibrata K M, Setyohadi B, Syam AF, editors. Buku Ajar Ilmu Penyakit Dalam. VI. Jakarta: InternaPublishing; 2014. p. 2359-66.

9. Subekti I. Neuropati Diabetik. In: Setiati S, Alwi I, Sudoyo AW, Simadibrata K M, Setyohadi B, Syam AF, editors. Buku Ajar Ilmu Penyakit Dalam. VI. Jakarta: InternaPublishing; 2014. p. 2395-9.

10. Waspadji S. Kaki Diabetes. In: Buku Ajar Ilmu Penyakit Dalam. VI. Jakarta: Setiati, Siti Alwi, Idrus Sudoyo, Aru W Simadibrata K, Marcellus Setyohadi, Bambang Syam, Ari Fahrial; 2014. p. 2367-74.

11. Antono D. Peran Intervensi Perifer pada Kasus Kaki Diabetik [Internet]. Medistra Hospital. 2015. Available from:

http://www.medistra.com/index.php? option $=$ com_content\&view $=$ article\&i $\mathrm{d}=175$

12. Comerota AJ, Throm RC, Kelly P, Jaff $\mathrm{M}$. Tissue (muscle) oxygen saturation (StO2): A new measure of symptomatic lower-extremity arterial disease. Vasc Surg [Internet]. 2003;38(4):724. Available from: https://pubmed.ncbi.nlm.nih.gov/1456 
0221/

13. Hastuti RT. Faktor-faktor Risiko Ulkus Diabetika Pada Penderita Diabetes Mellitus (Studi Kasus di RSUD Dr. Moewardi Surakarta). Tesis. Universitas Diponegoro Semarang; 2008.

14. Hopkins RB, Burke N, Harlock J, Jegathisawaran J, Goeree R. Economic burden of illness associated with diabetic foot ulcers in Canada. BMC Health Serv Res [Internet]. 2015;15(1):13. Available from: $\mathrm{http} / / / \mathrm{bmchealthservres.biomedcentral}$ .com/articles/10.1186/s12913-0150687-5

15. Widyawati IY. Universitas indonesia. Program Pasca Sarjana UI; 2010.

16. Yuwono P, Khoiriyati A, Sari NK. Pengaruh Terapi Pijat Refleksi Kaki Terhadap Ankle Brachial Index (ABI) pada Pasien Diabetes Melitus Tipe 2. Motorik. 2015;10 (20) :53-64.

17. Potter PA, Perry AG. Fundamental of Nursing. 7th ed. Crisp JC, Taylor C, editors. Jakarta: Salemba Medika; 2009. 1667 p.

18. Eurell JA, Frappier BL. Dellmann's Textbook of Veterinary Histology [Internet]. 6th ed. Victoria Australia: Blackwell Publishing Asia; 2006. Available from: https://books.google.co.id/books?id= GqiXUD_wwIC\&printsec $=$ frontcov er\&hl=id\&source=gbs_ge_summary_ $\mathrm{r} \& \mathrm{cad}=0 \# \mathrm{v}=$ onepage $\& \mathrm{q} \& \overline{\mathrm{f}}=$ false

19. Price SA, Wilson LM. Patofisiologi : konsep klinis proses-proses penyakit; Volume 1 / oleh Sylvia A. Price, Lorraine M. Wilson. Jakarta: EGC; 2006. xxv, 734 pages.

20. Hastuti TR. FAKTOR RISIKO PADA PENDERITA DIABETES MELLITUS. 2008.

21. Parameswaran GI, Brand K, Dolan J. Pulse Oximetry as a Potential Screening Tool for Lower Extremity Arterial Disease in Asymptomatic Patients With Diabetes Mellitus.
$2005 ; 165$.

22. Mar A, Moreno-lorenzo C, Matar GA, Feriche-fern B. Connective Tissue Reflex Massage for Type 2 Diabetic Patients with Peripheral Arterial Disease: Randomized Controlled Trial. 2011;2011.

23. Guyton AC, Hall JE. Buku Ajar Fisiologi Kedokteran. 11th ed. Jakarta: EGC; 2007.

24. Purwanto B. Spa Kaki Diabetisi. Yogyakarta: Gava Media; 2014.

25. Katuk ME. PENGARUH SENAM KAKI DIABETES TERHADAP NILAI ANKLE BRACHIAL INDEX PADA PASIEN DIABETES MELITUS. 2017;5.

26. Dagfinrud H, Christie A. Patients with rheumatoid arthritis feel better after exercises in warm water than after similar exercises on land. Aust $\mathrm{J}$ Physiother. 2007;53(2):130.

27. Suandika M. Pengaruh rendam kaki air hangat terhadap peningkatan sirkulasi darah perifer dilihat dari nilai. 2015;XIV(1):15-21.

28. Alviani P. Pijat Refleksi. Yogyakarta: Pustaka Baru Press; 2015. 